\title{
Some Common Diseases of Pepper in Florida ${ }^{1}$
}

\author{
Gary Vallad and Pamela Roberts ${ }^{2}$
}

Pepper is an important commercial vegetable crop in Florida with a value of \$206 million in 2017 (USDA NASS). Florida, California, and Georgia are the top three states producing most of the US crop. Peppers are primarily harvested from the field during the months of November through May. Bell peppers are produced in the highest quantity, but specialty peppers, such as jalapenos, cubanelle, mini sweets, and many other types, are also widely grown in Florida.

There are many diseases that can severely limit production of pepper in Florida. This EDIS document describes several commonly observed diseases and provides recommendations for their management. Because pesticide registrations and varieties change frequently, consult the Pepper Production chapter in the Vegetable Production Handbook of Florida (https://edis.ifas.ufl.edu/cv130) for current, specific pesticide recommendations, variety characteristics, and other commercial production information.

\section{Anthracnose}

The causal agent of anthracnose is a fungus within the genus Colletotrichum. Colletotrichum gloeosporioides and Colletotrichum acutatum are the two species found on pepper in Florida (Harp 2008; Lewis-Ivey 2004). Colletotrichum gloeosporioides is most commonly associated with causing lesions on ripe (colored) fruit, whereas C. acutatum produces lesions on immature (green) fruit (Harp et al. 2008). Anthracnose lesions can occur on leaves (Figure 1) and stems, but the fruit infections have the largest economic impact. Fruit symptoms begin as water-soaked lesions that are soft and slightly sunken. As the lesions age, they become covered with a wet, gelatinous spore mass. Fruit infected with $C$. acutatum will have lesions that are salmon-colored from the spore mass (Figure 2).

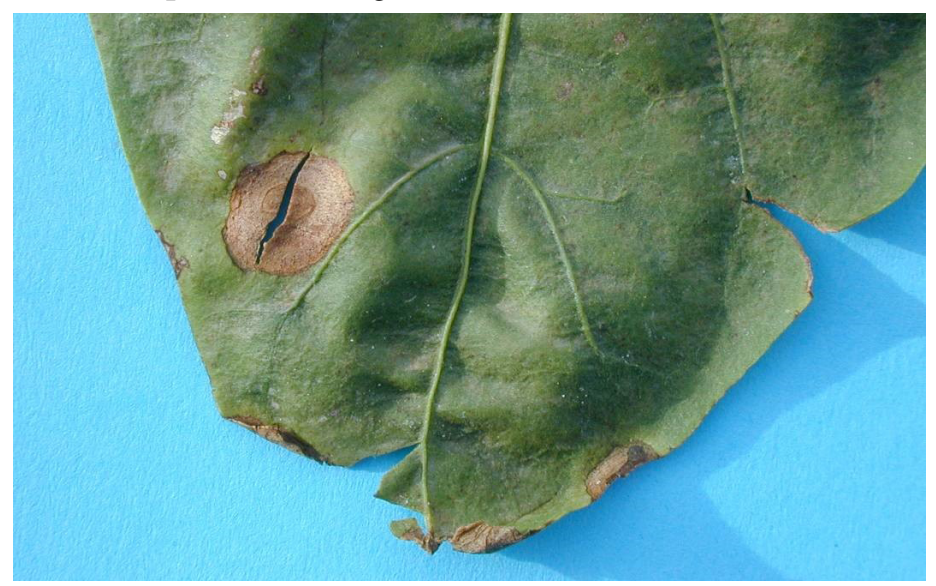

Figure 1. Pepper leaf with lesions typical of anthracnose. Credits: J. Mertely, UF/IFAS

The disease is more common during warm, wet weather, with the optimal temperature for development around $80^{\circ} \mathrm{F}$ $\left(27^{\circ} \mathrm{C}\right)$. Rainy weather increases disease severity due to the spread of spores via splashing onto other fruit. In addition to rain splashing, spores may be moved mechanically by workers or equipment that come into contact with infected plants. The pathogen is seedborne, and anthracnose may be introduced into the field on infected transplants, or it can survive between growing seasons in plant debris or on

1. This document is CIR946, one of a series of the Plant Pathology Department, UF/IFAS Extension. Original publication date March 1991. Revised September 2015 and October 2020. Visit the EDIS website at http://edis.ifas.ufl.edu.

2. Gary Vallad, associate Professor, Plant Pathology Department, UF/IFAS Gulf Coast Research and Education Center; and Pamela Roberts, professor, Plant Pathology Department, UF/IFAS Southwest Florida REC; UF/IFAS Extension, Gainesville, FL 32611. The original version of this article was written by Ken Pernezny, professor emeritus, Plant Pathology Department, UF/IFAS Everglades REC, Belle Glade, and Tom Kucharek, professor emeritus, Plant Pathology Department, UF/IFAS Extension, Gainesville, FL. 
alternate weed hosts, although alternative hosts have not been fully identified as occurring naturally in the field.

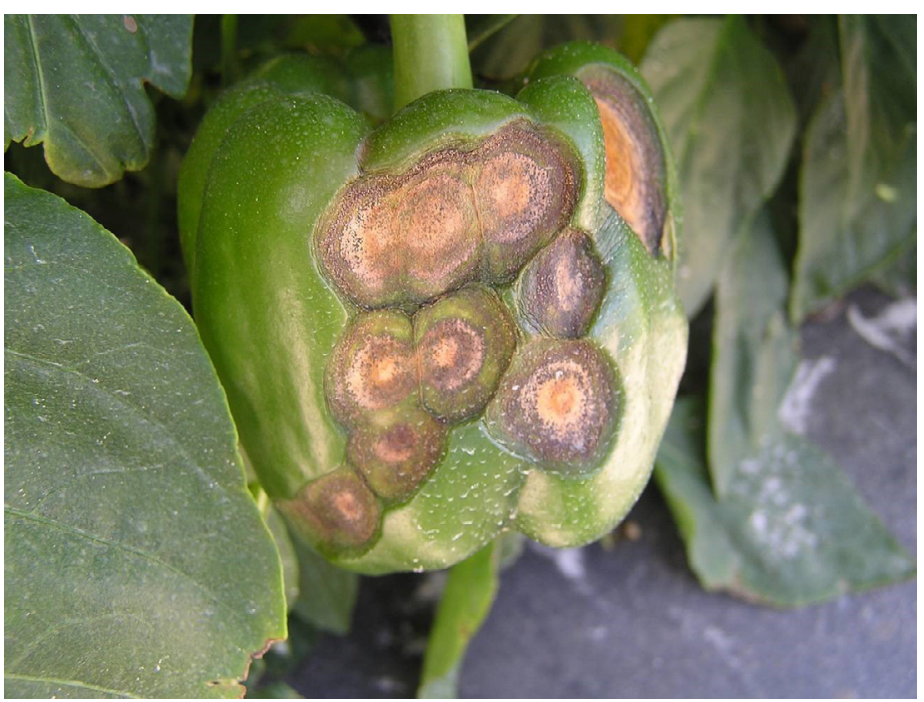

Figure 2. Pepper fruit with symptoms of anthracnose.

Credits: K. Pernezny, UF/IFAS

An integrated approach to disease management is required to control anthracnose. Select seed sources that are certified or known to be pathogen-free. Transplants should be kept clean by controlling weeds and solanaceous volunteers around transplant houses. Fields should have good drainage and be free from infected plant debris. If disease was previously present, crops should be rotated away from solanaceous plants for at least two years. Field sanitation practices include control of weeds and removal of volunteer pepper plants.

Resistance is available in some varieties of specialty peppers but not in bell peppers. For bell pepper production, choose a cultivar that produces fruit with a shorter ripening period. This may allow the fruit to escape infection by the fungus. Reduce chances of wounding fruit by managing insects and other means of damaging fruit. Wounds are known entry points for Colletotrichum spp. and other pathogens, such as bacteria that cause soft rot. At the end of the season, the crop debris should be destroyed to reduce spore survival for infecting subsequent crops. Application of fungicides may be needed to manage the disease. Currently registered fungicides for anthracnose can be found in the Vegetable Production Handbook of Florida, Pepper Production at https://edis.ifas.ufl.edu/cv130. For additional information, please refer to Anthracnose on Pepper in Florida (https:// edis.ifas.ufl.edu/pp104).

\section{Bacterial Spot}

Bacterial spot, caused by the bacterium Xanthomonas euvesicatoria, is the most common and serious foliar disease problem faced by Florida pepper growers. In southern Florida, most serious outbreaks are observed in the months of August through November, but outbreaks are possible whenever environmental conditions are favorable. Warm weather and frequent episodes of wind-driven rain increase likelihood of bacterial spot developing. When night temperatures are above $65^{\circ} \mathrm{F}$, bacterial spot infection is most severe.

All aboveground plant parts are susceptible to infection. In leaves, the first symptoms are water-soaked spots on the lower leaf surface within 3-4 days of infection (Figure 3). Within another 2-3 days, the lesions become tan to brown greasy spots on the upper leaf surface (Figure 4A). Leaf spots expand and coalesce to form large areas of yellow and brown tissue with a characteristic, greasy appearance (Figure 4B). Leaf margins may become scorched due to invasion of hydathodes by the bacteria. Infected leaves often drop prematurely, even when only moderate damage from bacterial spot is incurred.

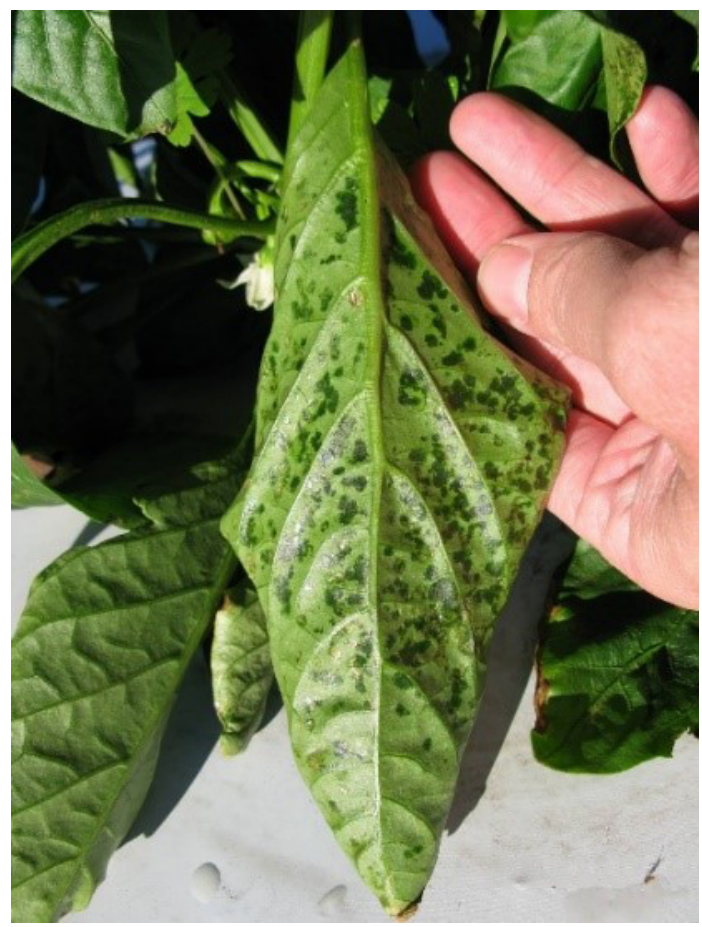

Figure 3. Pepper leaf exhibiting water-soaked lesions, the initial symptoms of bacterial spot, caused by Xanthomonas euvesicatoria. Credits: G. Vallad, UF/IFAS

Lesions on fruit appear initially as small, raised blemishes that are a slightly lighter green than the normal fruit color (Figures $5 \mathrm{~A}$ and $\mathrm{B}$ ). They enlarge and turn brown to black and appear as raised warts or scabs (Figure 5C). Under 
humid conditions, other microbes may enter the fruit at the bacterial spot lesions and cause massive fruit decay.

Bacterial spot management requires an integrated approach, which uses several tactics. Xanthomonas euvesicatoria can be divided into ten races based on several resistance genes in pepper. Some bell pepper varieties have resistance to all known races of $X$. euvesicatoria. Limited resistant varieties are found in other specialty peppers. The bacteria can be transmitted in pepper seed. Pepper and tomato volunteers should be destroyed well before the next cropping season. Inspect transplants for disease and only use healthy transplants. Water is critical for the spread and development of bacterial spot. Avoid overhead irrigation whenever possible. Workers and farm equipment should be kept out of fields when conditions are wet, because the bacteria is readily spread after contact is made with wet foliage.

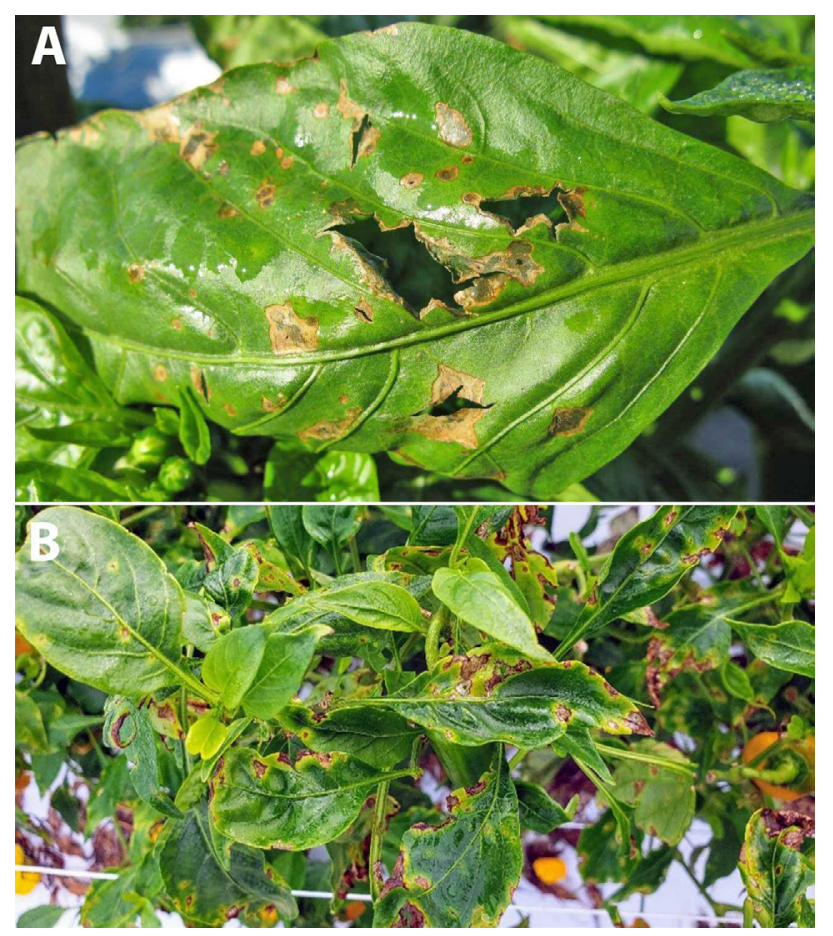

Figure 4. A) Pepper leaf exhibiting severe symptoms of bacterial spot, caused by Xanthomonas euvesicatoria. B) Lesions of bacterial spot on mini sweet pepper leaves.

Credits: A) G. Vallad, UF/IFAS; B) P. Roberts, UF/IFAS

Avoid unnecessary use of magnesium as foliar or soil applications. The effectiveness of copper bactericides is limited because of widespread copper tolerance among strains of $X$. euvesicatoria in Florida. It is recommended that any copper bactericide be combined with a dithiocarbamate fungicide, such as mancozeb. While the exact mode of action is still unknown, the addition of a dithiocarbamate fungicide increases copper solubility, which may account for the increased bactericidal activity. Numerous biopesticides are also labeled for bacterial spot control on pepper, but the efficacy and reliability of these products is limited. Best results are observed when biopesticides are used to augment the activity of standard copper-mancozeb applications. Biopesticides do not represent a viable replacement for the use of copper-mancozeb applications, especially for the control of copper-tolerant isolates of X. euvesicatoria.

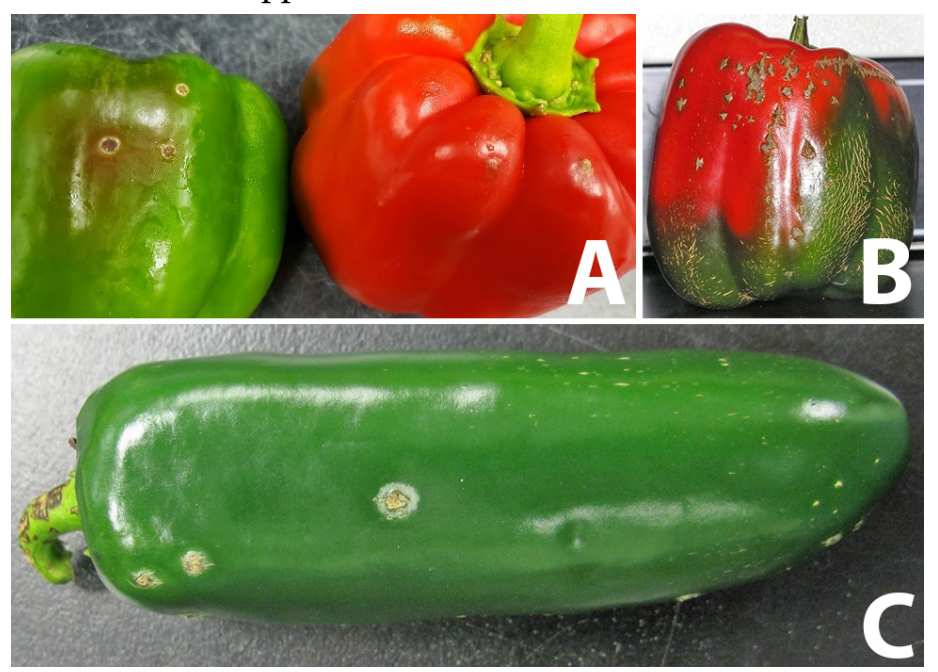

Figure 5. Lesions of bacterial spot caused by Xanthomonas

euvesicatoria on: A) bell pepper fruit; B) raised, scab-like lesions on bell pepper; and C) jalapeño pepper.

Credits: A) P. Roberts, UF/IFAS; B) K. Pernezny, UF/IFAS; and C) G. Vallad, UF/IFAS

\section{Phytophthora Blight}

Phytophthora blight, caused by the fungal-like organism Phytophthora capsici, can cause major losses when conditions are conducive for the disease. P. capsici is referred to as a water-mold, but it is more closely related to brown algae than true fungi. P. capsici forms lemon-shaped spores (sporangia) (Figure 6) among the mass of white growth that can subsequently produce many smaller zoospores that are motile in water. Special resting spores with thick walls, called oospores, are formed, which enable the pathogen to survive long periods of adverse conditions.

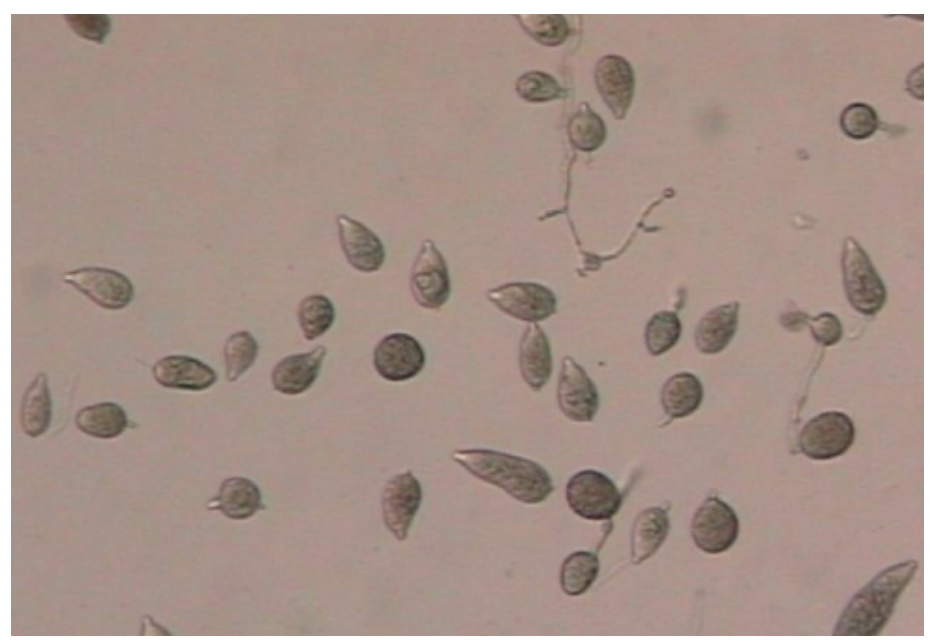

Figure 6. Sporangia of Phytophthora capsici.

Credits: P. Roberts, UF/IFAS 
P. capsici can infect all parts of the pepper plant. In many cases, the first symptom noted is overall general wilting of pepper plants (Figure 7A). The wilt occurs only after the development of lesions at any point on the stem. The stem lesions start as dark green, water-soaked spots or streaks that later develop a dark brown color (Figure 8). Wilting is seen above lesions that girdle side shoots or the main stem.

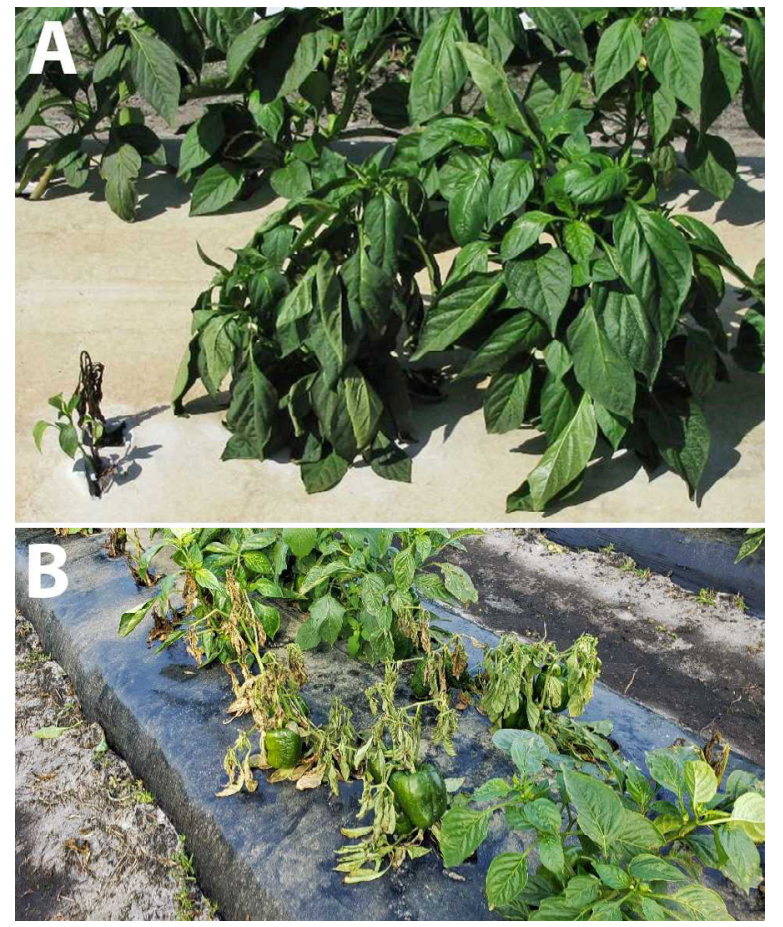

Figure 7. A) Wilted pepper plant from Phytophthora blight; and B) wilted pepper plant with fruit attached.

Credits: A) G. Vallad, UF/IFAS; B) P. Roberts, UF/IFAS

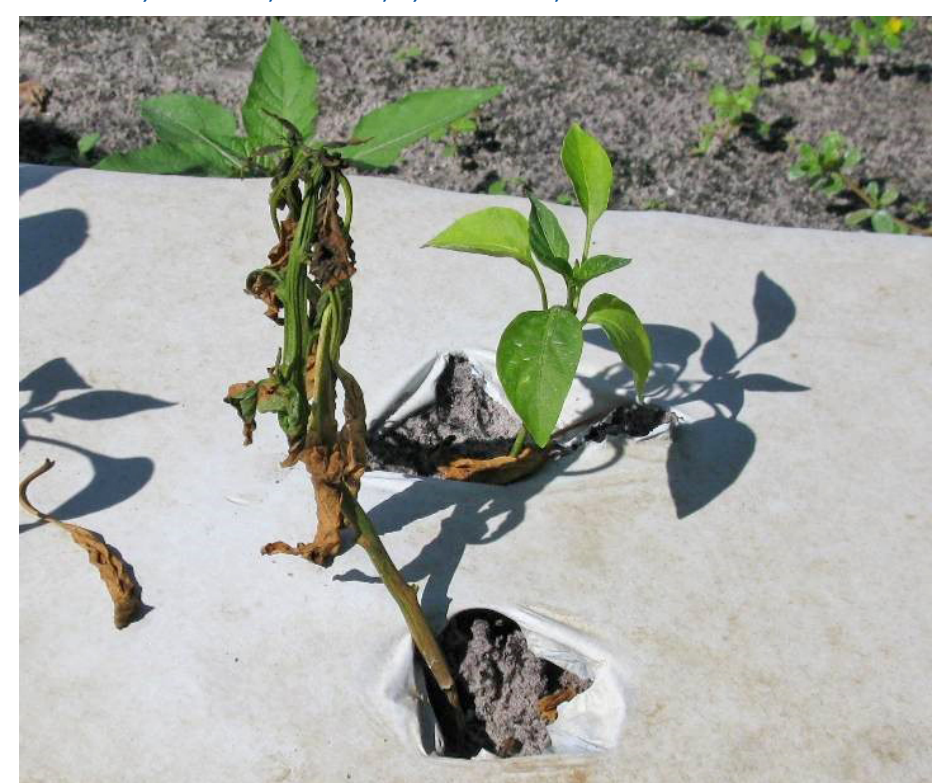

Figure 8. Brown lesions on pepper stem that are typical of Phytophthora blight.

Credits: G. Vallad, UF/IFAS

Fruit infection is common. The pathogen usually grows first through the fruit stalk. Fruits are then invaded, with a soft, mushy rot developing (Figure 9). The white growth of the pathogen is often evident on the surface of lesions. Fruits eventually shrivel up but remain on the plant for considerable periods of time (Figure 7B).

P. capsici has been reported to survive on seed as well as in soil as oospores. The lemon-shaped spores produced by the actively growing pathogen are readily spread by splashing rain. Some weeds have been identified that can serve as a reservoir of the pathogen (French et al. 2006). Surface water, such as in canals or retention ponds, can also be a source of inoculum (Roberts et al. 2005).

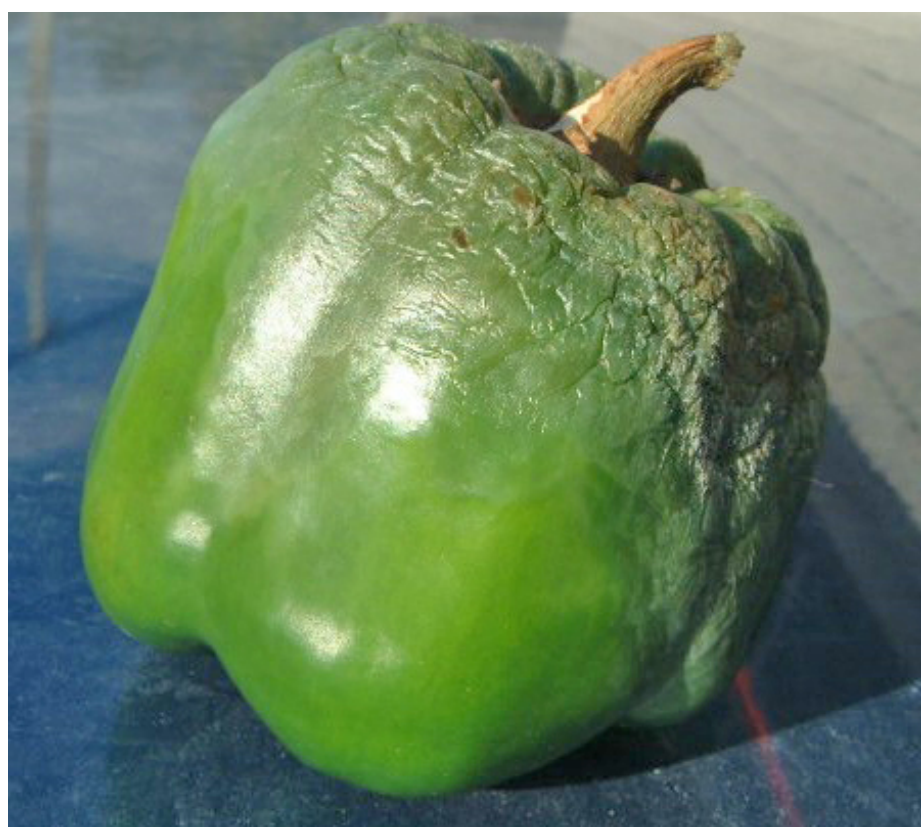

Figure 9. Fruit infected with Phytophthora capsici.

Credits: P. Roberts, UF/IFAS

P. capsici can be active during moist conditions with temperatures ranging from $46^{\circ} \mathrm{F}-91^{\circ} \mathrm{F}$, but optimum temperatures for activity range from $68^{\circ} \mathrm{F}-86^{\circ} \mathrm{F}$. Heavy rains during warm periods are highly favorable for development of this disease.

No one method is available to control P. capsici. The use of soil fumigation to reduce soil populations of the pathogen helps. Plastic mulch acts as barrier and reduces contact of soil populations of the pathogen with plants. It is recommended to plant pepper on well-drained soil. Fungicides may provide some control. Fungicides currently registered for this disease can be found in the Vegetable Production Handbook of Florida, Pepper Production at https://edis.ifas. ufl.edu/cv130. Maintain field sanitation by removing weeds and volunteer pepper plants, along with treating surface water used for irrigation. For additional information, see the EDIS document Vegetable Diseases Caused by Phytophthora capsici in Florida (https://edis.ifas.ufl.edu/vh045). 


\section{Wet Rot (Choanephora Blight)}

Wet rot, or Choanephora blight, has become increasingly more common and severe in recent years. The causal agent is the fungus Choanephora cucurbitarum. It is ordinarily thought of as a "weak" pathogen because it colonizes dead or dying tissue before actively invading living pepper tissue. Most infections begin in senescing flower petals. Once established, entire flowers are overgrown, resulting in a brown to black mass of soft tissue. Flower stalks, buds, and leaves may subsequently be invaded (Figure 10). Optimal spore production occurs between $77^{\circ} \mathrm{F}-86^{\circ} \mathrm{F}$. Diagnosis of wet rot in the field is based on the appearance of a silvery mass of fungal growth topped with a black ball made of great numbers of spores. The growth resembles whiskers growing out of the affected pepper tissue. The disease is not easily managed by traditional means. Reducing field conditions that favor moist conditions such as using drip irrigation may help. Fungicides labeled for pepper for other fungal diseases may provide some control of Choanephora blight.

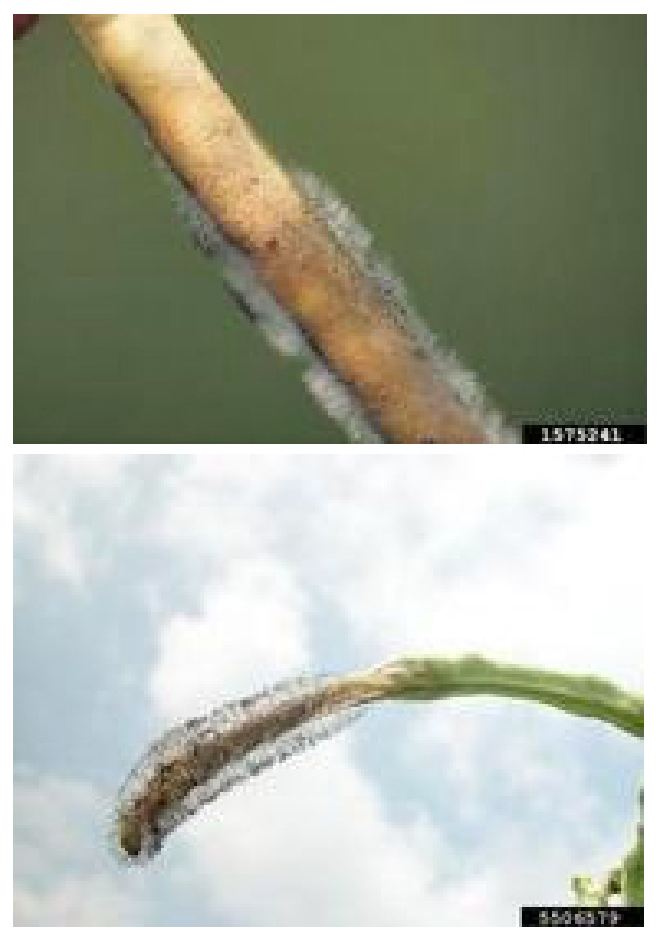

Figure 10. Masses of Choanephora fungal spores and the characteristic "whisker" appearance of the spore masses.

Credits: Gerald Holmes, Strawberry Center, Cal Poly San Luis Obispo, Bugwood.org

\section{Cercospora Leaf Spot}

Cercospora leaf spot, sometimes known as frogeye leaf spot, caused by the fungus Cercospora capsica, is common in northern Florida during the summer. It is becoming increasingly more prevalent in south Florida. The disease is usually most severe during warm, wet weather. Symptoms may occur in leaves, stems, petioles, and fruit stalks. However, it is the distinctive leaf lesions that allow it to be readily identified in the field. Spots are circular to oval, with light tan centers and dark red borders (Figure 11). Under very moist conditions, the fungus may be observed growing in the middle of the spot, especially if observed using a good hand lens. These spores are readily transmitted via wind.

The fungus can survive in Florida on crop debris. Prompt destruction of abandoned pepper crops and crop rotation are nonchemical methods of control. Currently registered fungicides for this disease can be found in the Vegetable Production Handbook of Florida, Pepper Production at https://edis.ifas.ufl.edu/cv130.

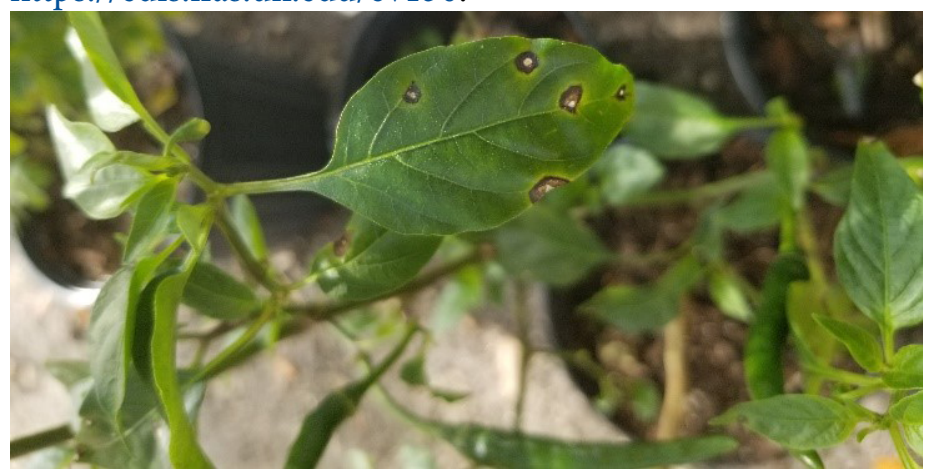

Figure 11. Small circular to oval spots, with light tan centers and dark red borders typical of frogeye spot.

Credits: G. Vallad, UF/IFAS

\section{Southern Blight (White Mold)}

Pepper is included in the wide host range of the southern blight fungus, Sclerotium rolfsii. This disease has been more problematic in the northern part of the state. The major symptom is a rapid wilting of plants (Figure 12). Internal and external lower stem tissue is infected and discolored by this fungus. The disease can be definitively diagnosed by finding small, mustard-seed-sized resting structures, called sclerotia, at the base of stems (Figure 13). Sclerotia will begin as white structures and later darken to shades of orange to dark brown. Southern blight is favored by high temperatures of $80^{\circ} \mathrm{F}-95^{\circ} \mathrm{F}$.

Control is achieved by crop rotation with nonsusceptible crops, such as grasses. However, because sclerotia are heavily resistant to adverse conditions, long rotations of crops over several years are best. Care must be taken not to transmit sclerotia within or between fields on farm equipment or shoes of workers. Sclerotia may also be transmitted in runoff from rain or irrigation. Turning soil with a moldboard plow rather than disking prior to planting is the preferred management scheme. Some control may be obtained from the use of broad-spectrum soil fumigants. 
These are usually applied when the full-bed, plastic mulch system is used for production of pepper. Refer to the EDIS publication Integrated Management of Southern Blight in Vegetable Production (https://edis.ifas.ufl.edu/pp272) for additional details.

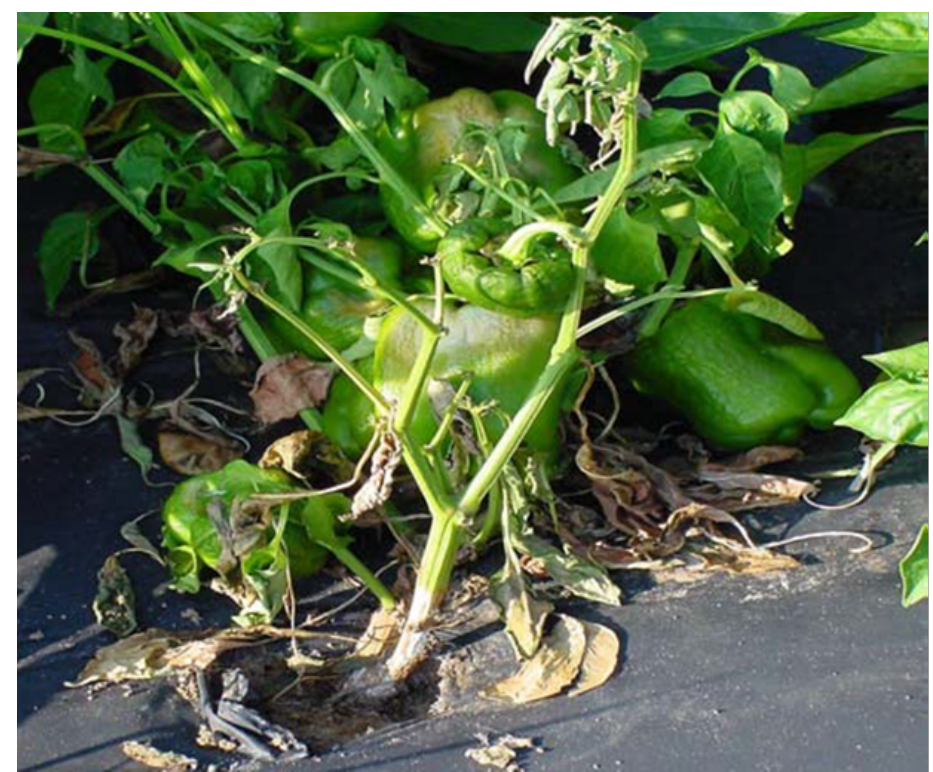

Figure 12. Wilted pepper plant infected with Sclerotium rolfsii causing southern blight with typical white mycelial growth at plant crown. Credits: G. Vallad, UF/IFAS

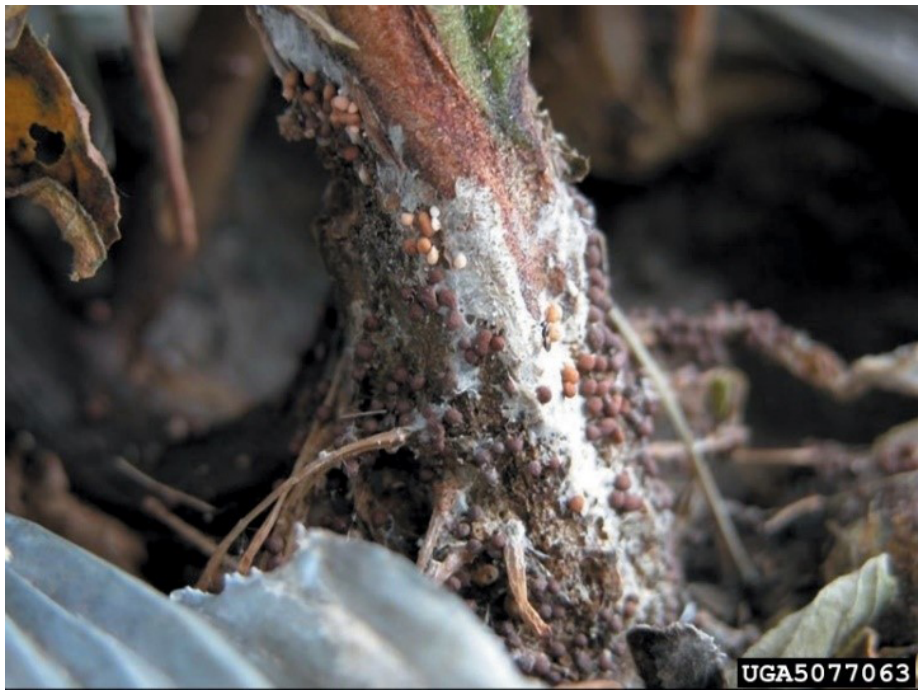

Figure 13. Mustard-seed-like sclerotia on plant at soil line.

Credits: David B. Langston, University of Georgia, Bugwood.org

\section{Blossom End Rot}

Blossom end rot is an abiotic problem, meaning that a living microorganism does not initiate this disease. Damage is confined to the fruit. Symptoms begin as water-soaked spots at the blossom end or side wall of the fruit. Damaged areas expand and become sunken, tan to brown in color, and dry with a papery or leathery feel. The affected fruit areas become covered with saprophytic fungi, which appear as black feltlike growth on the fruit (Figure 14). It is important to note that these dark-colored fungi are not the cause of blossom end rot. Rather, they merely colonize damaged fruit tissue. This disorder is directly related to calcium deficiency in developing fruit. Low calcium levels in fruit can be the direct result of insufficient calcium in the soil. It may also be an indirect result of competition from high levels of ions such as magnesium. Severe fluctuations in the water status of plants (as when drought stress occurs among plants) accentuate calcium deficiency in fruit. Control is based on proper calcium nutrition of the crop and optimum irrigation scheduling. Refer to the EDIS publication Blossom-End Rot in Bell Pepper: Causes and Prevention (https://edis.ifas.ufl.edu/ss497) for additional details.

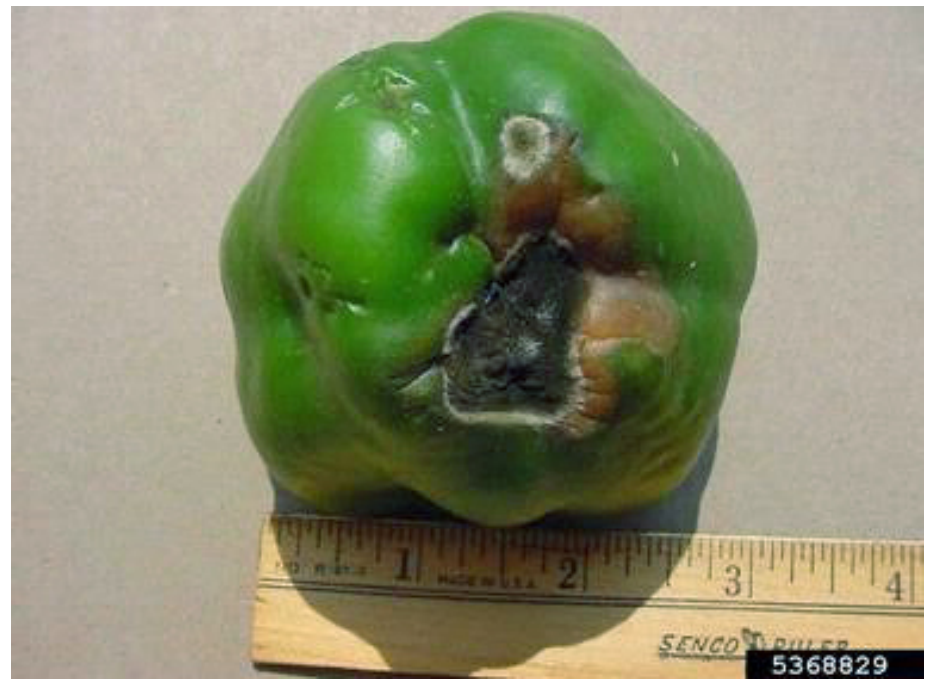

Figure 14. Symptoms of blossom end rot on pepper fruit and a secondary infection of fungi.

Credits: Paul Bachi, University of Kentucky Research and Education Center, Bugwood.org

\section{Tobacco Mosaic Virus and Pepper Mild Mottle Virus}

Tobacco mosaic virus (TMV) and pepper mild mottle virus (PMMV) are members of the tobamovirus family. TMV is one of the oldest known viral pathogens affecting pepper. TMV and PMMV have not been major problems in peppers in Florida but are occasionally detected. Many strains of the virus exist, and symptoms of the disease vary depending on the particular strain of virus and cultivar of pepper. The virus is active over a broad range of temperatures, light regimes, and nutrient situations.

Symptoms of TMV and PPMV are more or less typical of those associated with virus infections of a great number of crops. Leaves are mottled and distorted (Figure 15). Plants are often stunted. Fruits may also be distorted in shape and show mottling. Systemic symptoms occur in many strain/ 
cultivar combinations. In these cases, plants may wilt, exhibit extensive yellowing, and die.

TMV may be introduced into fields in transplants, in crop debris, and on hands or clothing of workers. It can also be transferred by contaminated tools and machinery. Workers can get TMV-laden sap from infected plants on their hands and readily transmit the virus from plant to plant down the row. Some tobacco products used by workers can be a very important source of TMV. The viruses are also seedborne.

Control of tobamoviruses centers on reduction of initial inoculum. Use of clean transplants and crop rotation are important. Cultural practices should be designed to minimize manipulation of plants. Workers should wash hands and use suggested practices for tools as described in the EDIS publication Disinfection of Horticultural Tools at https://edis.ifas.ufl.edu/ep380. There are differences in resistance to TMV among pepper varieties. For additional information, please see the EDIS publications Pepper Mild Mottle Virus (https://edis.ifas.ufl.edu/cv275) and Common Pepper Cultivars for Florida Production (https://edis.ifas.ufl. edu/in757).

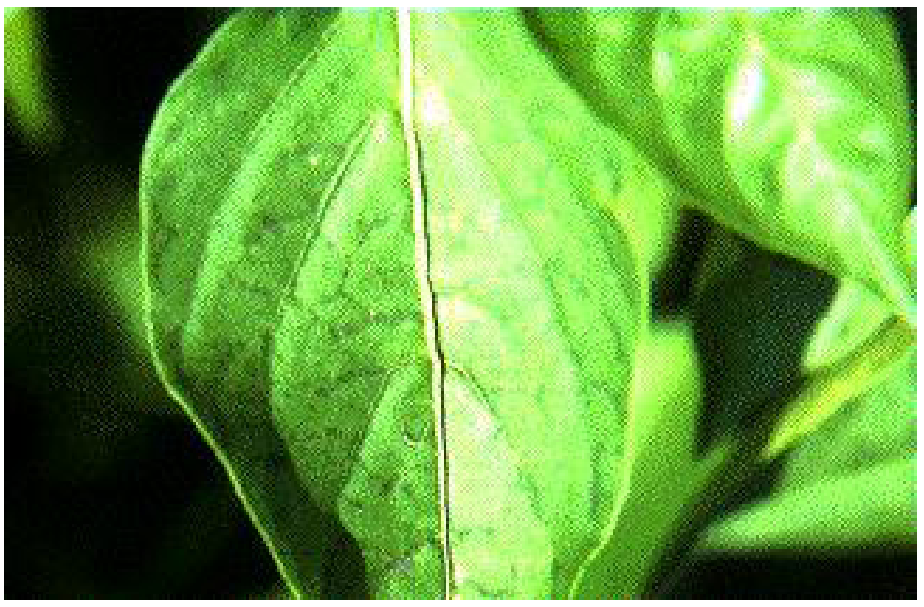

Figure 15. Leaf mottling and distortion on plants infected with tobacco mosaic virus.

Credits: T. Kurachek, UF/IFAS

\section{Aphid-Transmitted Viruses}

Pepper mottle virus (PeMoV), potato virus Y (PVY), and tobacco etch virus (TEV) are aphid-transmitted viruses that have caused serious problems throughout Florida. Cucumber mosaic virus (CMV) is more common in the southern part of the state. It is very difficult to specifically diagnose which virus or viruses are affecting a plant based on field symptoms alone. A plant disease diagnostic clinic should be used to ensure accurate identification of the virus. More information about diagnostic services and locations can be found in the EDIS document The Florida Plant Diagnostic Network (https://edis.ifas.ufl.edu/pp151). Symptoms can be similar for all of these viruses. A mosaic pattern (blends of light and dark green-yellow areas) with distortion is common in leaves of plants infected with PeMoV, PVY, or TEV. The small leaves at the top of the plant may be crinkled. Plants may be stunted. Veins in leaves may be banded a darker green than the background tissue (Figure 16). Fruit mottling, distortion, and uneven ripening are not uncommon. PeMoV can cause mild or severe distortion of fruit and leaves. CMV-infected plants may show large yellow ringspots and oak-leaf patterns.

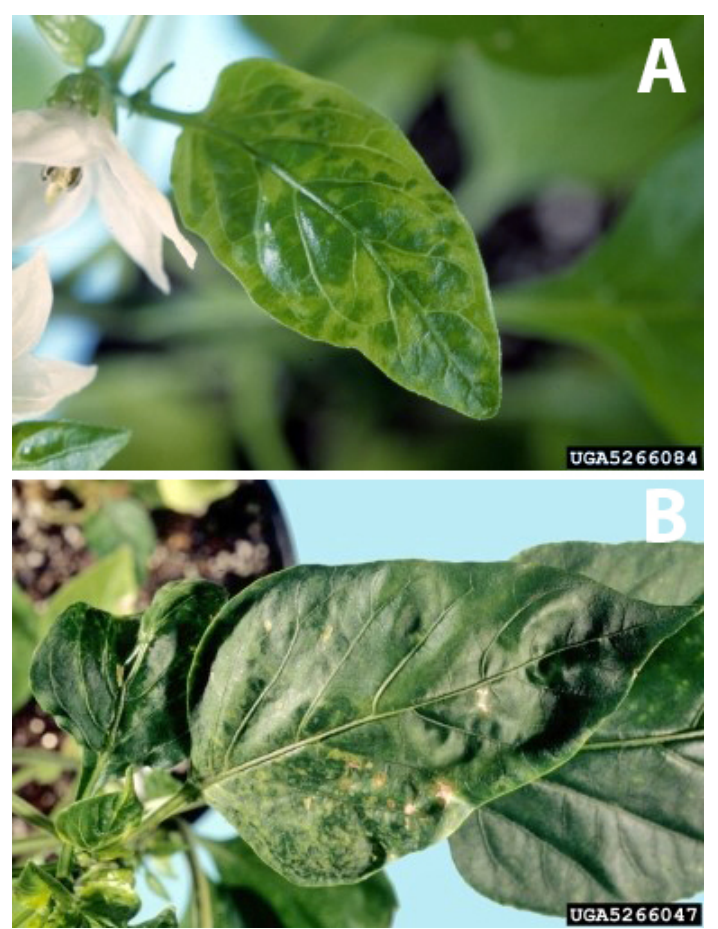

Figure 16. A mosaic pattern (blends of light and dark green-yellow areas) with distortion is common in leaves of plants infected with A) cucumber mosaic virus; and B) tobacco etch virus.

Credits: Florida Department of Plant Industry

These four viruses are transmitted by aphids in a "nonpersistent" manner, that is, the viruses are not taken up into the aphid, but remain on the outside of the insect's feeding probe. The aphids acquire the virus by feeding on infected weed or crop plants. Transmission or acquisition of the virus by feeding is accomplished in seconds. Therefore, insecticides provide little control. Aphids lose the ability to effectively transmit these viruses by one hour after acquisition. Disease occurrence parallels closely the fluctuations in aphid populations. Traditionally, these viral diseases have been worse in the cooler and drier months of the winter and early spring when aphids abound.

Numerous tactics have been identified to help manage these diseases. Source plants of these viruses include abandoned pepper crops and the weeds black nightshade and ground 
cherry. These should be identified and destroyed. Reflective mulches have been shown to repel aphids. Repeated sprays of light petroleum oil (e.g., JMS stylet oil) reduce infection by coating the foliage with a layer of material that inactivates the virus. Resistant varieties can be used. In southern Florida, earlier fall plantings tend to avoid peak aphid flights. However, such plantings are likely to incur more damage from bacterial spot. Growers in northern Florida are encouraged to purchase disease-free transplants.

\section{Tomato Spotted Wilt Virus (TSWV) and Tomato Chlorotic Spot Virus (TCSV)}

TSWV and TCSV are tospoviruses that are spread primarily by thrips. Mechanical transmission is also possible. Both viruses can kill plants or cause symptoms such as stunting, mosaics in leaves and fruit, or necrosis (browning) (Figure 17). TSWV and TCSV have caused severe damage in tobacco, tomato, beans, and many other field, vegetable, fruit, and ornamental crop species. An intensive, integrated management program is necessary for reducing these severe diseases, and more detailed information on these viruses, thrips, and their management can be found in the EDIS publication Tomato Chlorotic Spot Virus at https:// edis.ifas.ufl.edu/pp306, and Managing Thrips in Pepper and Eggplant at https://edis.ifas.ufl.edu/in401.

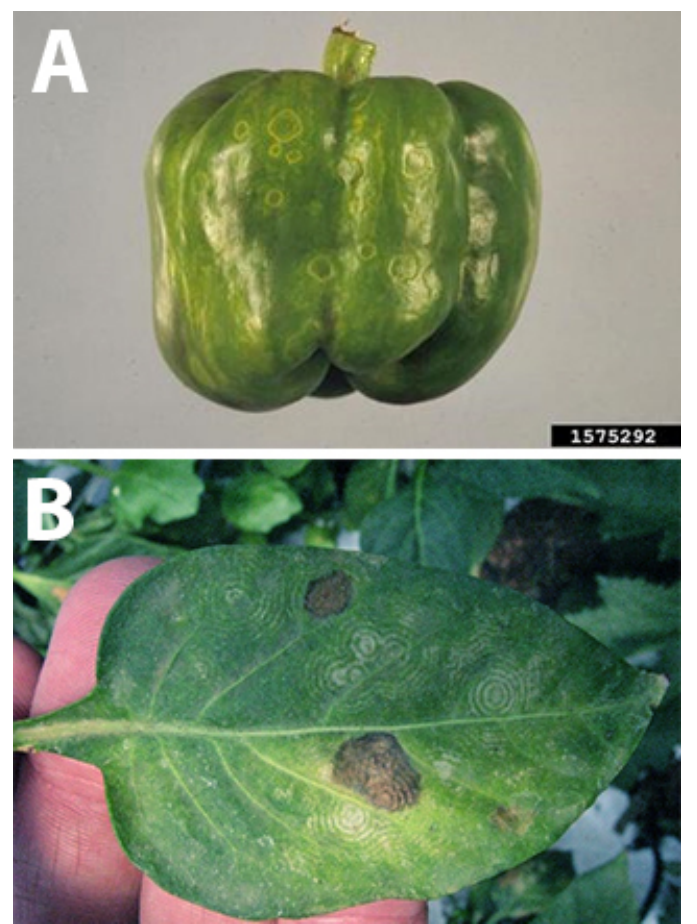

Figure 17. Tomato Spotted Wilt Virus symptoms on A) pepper fruit; and B) leaves.

Credits: A) Gerald Holmes, Strawberry Center, Cal Poly San Luis Obispo, Bugwood.org; B) G. Vallad, UF/IFAS

\section{References}

French-Monar, R. D., J. B. Jones, and P. D. Roberts. 2006. "Characterization of Phytophthora capsici associated with roots of weeds on Florida vegetable farms." Plant Dis. 90:345-350.

Harp, T. L., K. Pernezny, M. L. Lewis Ivey, S. A. Miller, P. J. Kuhn, and L. Datnoff. 2008. "The etiology of recent pepper anthracnose outbreaks in Florida." Crop Protection 27:1380-1384.

Lewis-Ivey, M. L., C. Nava-Diaz, and S. A. Miller. 2004. "Identification and management of Colletotrichum acutatum on immature bell peppers." Plant Dis. 88:1198-1204.

Roberts, P. D., R. R. Urs, R. D. French-Monar, M. S. Hofficen, T. E. Seijo, and R. J. McGovern. 2005. "Survival and recovery of Phytophthora capsici and oomycetes in tailwater and soil from vegetables fields in Florida." Annals of Applied Biology 146:351-359. 